\title{
The process of opening innovation networks: open innovation at Embrapa Florestas
}

\author{
Filipe Carvalho Vieira and Leandro R.C. Bonfim \\ Administração, Universidade Estadual do Parana - Campus de Paranagua, \\ Paranagua, Brazil, and \\ Aline Cristina da Cruz \\ Ciências Econômicas, Universidade Federal de Sao Joao del-Rei, \\ São João Del Rei, Brazil
}

\begin{abstract}
Purpose - The purpose of this paper is to map the process of opening an innovation network in the context of the Brazilian agroforestry sector.

Design/methodology/approach - Qualitative case study of the open innovation network Embrapa Florestas (17 semi-structured interviews, observation and documentary data). Social network analysis (SNA) of the open innovation network from primary data is available at Embrapa Florestas' system.

Findings - Three primary triggers to the opening process of Embrapa Florestas' innovation network were identified. The process starts with an innovation network with closed network characteristics. The process of opening the innovation network is motivated by a restructuring in its source of fundraising (trigger 1), by the change in strategic orientation toward the internationalization of its network activities (trigger 2) and by opening the black box of its innovation with greater proximity to the productive sector and partner universities (trigger 3). Comparing the pre-opening and post-opening networks (open innovation network), sociometric data allows us to verify that the opening of the innovation network presents better density, clustering and centrality indexes for the network as a whole and for the Embrapa Florestas specifically.

Originality/value - This is one of the first studies that aims to investigate the transition from a closed innovation network to an open innovation network by a public research institute. It may also be considered innovative because it presents practical and managerial relevance - in addition to contributions to public policy makers - which allows for improvements in the development of innovation and technology in the country's strategic sectors.
\end{abstract}

Keywords Open innovation network, Public research institutes, Open innovation, Forestry sector

Paper type Case study

\section{Introduction}

Open innovation explores organizations' intentional knowledge sharing embedded in the economic context (Chesbrough, 2003, Loukis, Charalabidis, \& Androutsopoulou, 2017). Although it is usually adopted in the private sphere, such strategy is also advocated within public organizations (Gascó, 2017, Kankanhalli, Zuiderwijk, \& Tayi, 2017). In this context, public research institutes (PRIs) become key organizations in promoting technological innovations by integrating private sector partners in open innovation (Sucupira, Saab, Demo,

(C) Filipe Carvalho Vieira, Leandro R.C. Bonfim and Aline Cristina da Cruz. Published in Innovation \& Management Review. Published by Emerald Publishing Limited. This article is published under the Creative Commons Attribution (CC BY 4.0) licence. Anyone may reproduce, distribute, translate and create derivative works of this article (for both commercial and non-commercial purposes), subject to full attribution to the original publication and authors. The full terms of this licence maybe seen at http:// creativecommons.org/licences/by/4.0/legalcode

This study was financed in part by the Coordenação de Aperfeiçoamento de Pessoal de Nível Superior - Brasil (CAPES) - Finance Code 001.

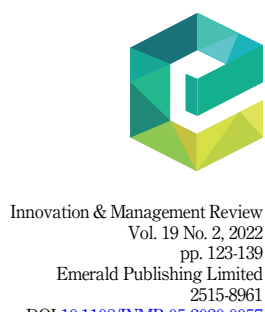


INMR

19,2

124
$\&$ Bermejo, 2019). Thus, they enable, for example, the effective participation of citizens and private companies in their fields of activity (Gascó, 2017).

Considering the Brazilian context of research, development and innovation (RD\&I), studies show that this has historically been conducted by public institutions (Chagas \& Ichikawa, 2009, Crespi, Rezende-da-Costa, Preusler, \& Porto, 2019). However, due to recent economic and fiscal crises, PRIs have been suffering from increasing budget cuts that impose additional obstacles to their RD\&I demands, making them increasingly dependent on external sources of subsidy. In this sense, the creation of open innovation networks presents itself as an effective mechanism for maintaining national RD\&I activities (Gascó, 2017, Laursen \& Salter, 2006, Vieira, Vale, \& May, 2018).

The adaptation to this new reality results in the compulsory requirement of open innovation processes within the very funding edicts of Brazilian official bodies, compelling research institutes to adapt to these new criteria (Chagas \& Ichikawa, 2009, p. 96). However, despite the demonstrated relevance of the phenomenon for innovation and technological development (Faccin \& Brand, 2015, Freitas, Filardi, Lott, \& Braga, 2017), studies investigating the process of opening the innovation networks and the consequent adoption of the open innovation model within public research institutes are still scarce. Thus, this article's guiding question is: how does the process of opening an innovation network of a public research institute occurs?

To address this research question, a single case study was conducted in a PRI of the agroforestry area, namely the Brazilian Agricultural Research Corporation (Empresa Brasileira de Pesquisa Agropecuária, abbreviated as the Embrapa) and, more specifically, the Forestry Unit (Embrapa Florestas, abbreviated as the EF). Its purpose is the effective transfer of the results of forestry research for the benefit of society, alongside with technical assistance and rural extension agencies, as well as cooperatives with common agendas, research institutes, national and international universities, and companies with different sizes (Crespi et al., 2019). Through a combination of physical infrastructure, human capital and partners, $\mathrm{EF}$ has been recognized as one of the best structured forestry research institutions in Latin America.

The results show that three primary triggers gave impulse to the process of opening the EF's innovation network. The process started from an innovation network that initially presented characteristics of a closed one, undergoing a restructuring in its source of resources (trigger 1). Later, there was a change in strategic orientation toward the internationalization of its network activities (trigger 2) and the opening of the black box of its innovation through greater closeness with the productive sector and partner universities (trigger 3). After comparing the sociometric data of the pre-opening and post-opening networks (open innovation network), the open innovation network allowed the EF to better act as a broker in the network, facilitating the flow of information and resources to the actors, occupying, therefore, the network periphery.

We contribute to the open innovation literature by demonstrating that the process of opening innovation networks allows overcoming a static view of open innovation, as seen in Faccin and Brand (2015). Also, this research contributes to the literature by identifying specific mechanisms for opening innovation networks within PRIs, whereas previous studies focus on networks composed of small and medium-sized firms (Brown \& Mason, 2014, Puliga, Manzini, Lazzarotti, \& Batistoni, 2020) or large multinationals (Dittrich \& Duysters, 2007). Finally, this research also contributes to the innovation network literature by demonstrating what type of open innovation network structure is verified after a transition process from a closed innovation network to an open innovation network.

The article is structured as follows. In the next section, the theoretical framework of innovation networks and open innovation is discussed, followed by the presentation of the case and research methods and the results (innovation network opening process and network 
structural mapping). Finally, theoretical, managerial and policy implications are presented, as well as possibilities for future research.

\section{Theoretical framework}

\subsection{Innovation networks}

Companies in public or private sphere face constant pressure for achieving positive socioeconomic results from innovations. They find, in innovation networks, their primary facilitating source of innovation processes (Hage \& Hollingsworth, 2000). The particularity of innovation networks lies in the process of knowledge generation, which occurs through its agents' interaction. By establishing these networks, organizations aim to integrate several institutions with complementary capabilities (Chagas \& Ichikawa, 2009), allowing the development of innovation in a cooperative way. Differentiation, interdependence and flexibility are among the determinant factors in establishing innovation networks (Conejero, Calia, \& Sauaia, 2015).

Innovation networks differ from interorganizational relationships in three aspects: (1) the fact that innovation networks integrate diverse sectors of the economy, (2) given the number and diversity of actors, innovation networks are usually formalized through agreements and contracts and (3) competition and cooperation among members are foreseen in the network configuration (Dias, Hoffmann, \& Martínez-Fernandez, 2019). Furthermore, innovation networks allow the coordination of knowledge among network members. They promote intercompany learning, enabling the integration of resources and establishing an organizational and interorganizational environment responsible for enabling the exploitation of synergies acquired by the convergence of distinct technological competencies (Oliveira, Mesquita, Castro, \& Sousa-Soares, 2012).

We emphasize that the formation of innovation networks in emerging countries, as Brazil's case, can be a possible way out, so that companies can innovate technologically (Chagas \& Ichikawa, 2009). In addition, there is effective innovation and frontier technological development in strategic sectors for the country, and these can and should be regarded as forms of public policies for innovation (Bonfim, Segatto, \& Gonçalves, 2018).

But how do these networks work? According to Hage and Hollingsworth (2000), innovation networks have two essential properties: their shape and the strength of the connectedness within and between the innovation networks. Thus, the connection between the organizations that make up the network allows for more effective communication, leading to more satisfactory results. Communication in a more direct way enhances innovation, whether radical or incremental (Bonfim, Gonçalves, Segatto, \& Jacometti, 2020). The adoption of the innovation networks model involving public organizations provides more significant social gains by promoting public policies that meet society's demands (Hage, Mote, \& Jordan, 2013).

As discussed so far, it can be inferred that the organization in innovation networks can be beneficial to both business and society. However, Randhawa, Wilden, and Hohberger (2016) point out that it is simply not enough to organize into a network. Public organizations need, when establishing their innovation networks, to foster open innovation practices. In the next section, we discuss the main developments and applications of open innovation in the context of innovation networks.

\subsection{Open innovation}

Open innovation is the "intentional use of internal and external flows of knowledge to accelerate internal innovation and increase markets for external use of innovations" (Chesbrough, 2003, p. 1). In this regard, organizations can use ideas from partners to leverage innovation at Embrapa Florestas 
INMR

19,2 their innovation process (Laursen \& Salter, 2006) and commercialize internally generated ideas through external channels (Lichtenthaler, 2008). Enkel and Gassman (2010) categorize open innovation processes into three types. The first is the search for and acquisition of external sources of innovation, the outside-in process. The second deals with the commercialization of proprietary processes and technologies, which are not incorporated into its strategy and business model (inside-out process). The third, the coupled process, links outside-in and inside-out processes. The open innovation's distinct forms are based on the direction of knowledge flow and the organization's boundaries (Enkel \& Gassman, 2010).

Although open innovation has gained attention in the scientific literature regarding private companies, such practice also benefits the public sector (Kankanhalli et al., 2017). In addition to the fundamental differences in ownership, funding and control originating in the sector, public organizations continue to maintain distinct characteristics, demonstrating that very little is still known about open innovation application in the public organizational context (Ribeiro, Salles-Filho, \& Bin, 2015).

It is emphasized that such public organizations hold "the requirement to disclose, license and share their knowledge and technologies to be commercially exploited by private companies" (Schillo \& Kinder, 2017, p. 6). They are responsible for supporting the private sector in its innovative processes and contributing positively to societal challenges (Crespi et al., 2019). Therefore, unlike the private sector, whose focus is on monetary and marketing returns, PRIs have multiple citizen-oriented goals, which must be managed simultaneously (Schillo \& Kinder, 2017).

Finally, as pointed out by Chesbrough (2003) and Randhawa et al. (2016), by practicing open innovation, public organizations establish ties with other society segments. Thus, there is an excellent approximation between open innovation concepts and the theoretical perspective of innovation networks discussed earlier. In addition, there is increased attention given to the literature to understand the processes of opening innovation networks (CamposOliveira, Leon-Olave, Moreno, \& Silva, 2020; Leminen, Nyström, \& Westerlund, 2020). However, despite this greater attention, there is still a lack of studies that make possible to understand how this process occurs in a naturally closed environment as innovation companies and Brazilian public research institutes are characterized (Stal, Nohara, \& Chagas, 2014; Puliga et al., 2020).

\section{Methods}

\subsection{Research context}

The Embrapa Florestas (EF) unit is one of 46 decentralized units of the Empresa Brasileira de Pesquisa Agropecuária (Brazilian Agricultural Research Corporation - Embrapa), among the seven in the Southern Region of Brazil, categorized in the product area (Crespi et al., 2019). The EF was established in Colombo, Paraná in 1978 through the creation of the National Forestry Research Program (PNPF). It resulted from the articulation between Embrapa and the Brazilian Institute for Forestry Development (IBDF). This process delegated Embrapa to coordinate, execute and support national forestry research. Embrapa Florestas' actions are essentially focused on producing technologies, information, services and generated and transferred knowledge.

These actions focus on the sustainability of forest plantations and agroforestry, natural ecosystems, conservation and use of forest genetic resources, control of pests and forest disease areas, adding value to forest products, forest planning and environmental education. Its relevance as a unique case is justified since Embrapa Florestas is a leading public institute in the forestry sector that has been changing its orientation from innovation to networks open to private sector actors (Crespi et al., 2019). 
The method adopted was a single case study (Yin, 2010) of Embrapa Florestas' innovation network's opening process and was held in two phases: the first, a qualitative analysis, and the second, a social network analysis (Hanneman \& Riddle, 2005). The first part of the data collection consisted of identifying the projects involving the Open Innovation Network of Embrapa Florestas' Unit (48 projects were already completed and evaluated, 28 projects were completed without evaluation and 30 are still running). Then, 14 researchers and managers from $\mathrm{EF}$ and three stakeholders from finished and ongoing projects were interviewed (semistructured interviews). The interviews with audio recordings were transcribed with Express Scribe Transcriptions v 6.10 software (I9, I13 and S2 did not authorize recording). Transcriptions were later analyzed with Altas.ti software to categorize, organize and record the obtained data (Bandeira-de-Mello, 2006). Detailed field notes on all interviews were prepared, but a greater emphasis was placed on the interviews that could not be recorded and transcribed. Table 1 presents each conducted interview description, each actors' position and the total duration of each interview.

Two direct nonparticipant observations were conducted at project meetings with stakeholders during field visits and $\mathrm{EF}$ events. The observations allowed us to verify the realtime phenomenon (Yin, 2010), originating detailed reports and field notes for further analysis. Primary and secondary data of a documental nature were also collected. Data were made available through access to the EF's computer system, being: (1) research projects, (2) legal contracts, (3) transparency portal, (4) technical-scientific reports and (5) management reports. These data allowed both the construction of the sociometric matrices for social network analysis (SNA) and the triangulation of evidence, especially concerning the interviews' information (Yin, 2010). Table 2 details the secondary data sources used in the research.

As for data analysis, the content analysis was the adopted technique for qualitative data (interviews, observations and documents). We carried out content analysis in the following stages (Bardin, 2011): (1) pre-analysis (organization of ideas, data collection and operationalization), (2) exploration of materials (data coding) and (3) result/inference (synthesization, selection and interpretation). As for the SNA, the files' information was entered into Excel Software to build a valued sociometric matrix. The sociometric matrix was adopted because it allows the measurement of the strength of ties and the center-periphery analysis (Hanneman \& Riddle, 2005), providing greater accuracy in interpreting the results. A value of 1 (one) was assigned in the perception of interfirm ties, and a value of 0 (zero) in the absence of ties was assigned to elaborate the valued matrix. In cases of repetition of the relationship between two organizations, we summed it in the sociometric matrix. Such procedure made it possible to detect the number of executed projects established by the other organizations, along with the EF. Finally, the estimated network's sociometric and egocentric data were extracted from the Ucinet Software, version 6.647.

\section{Results}

\subsection{The process of opening the innovation network}

The data made it possible to identify three primary triggers that gave impetus to the process of opening up EF's innovation network. As Figure 1 illustrates, the process started from an innovation network that initially $\left(t_{0}\right)$ presented a closed network's characteristics $(A)$. In the following period $\left(t_{1}\right)$, EF undergoes opening the innovation network $(A \rightarrow B)$. This process was driven by a restructuring in its source of fundraising (trigger 1), the change in EF's strategic orientation toward the internationalization of its networking activities (trigger 2) and the opening of the black box of its innovation through closer ties with the market (productive sector) and partner universities (trigger 3). Finally, in the third period $\left(t_{2}\right), \mathrm{EF}$ begins to present characteristics of an open innovation network (B), being considered a 


\begin{tabular}{|c|c|c|c|}
\hline & & & \\
\hline $\begin{array}{l}\text { INIVIR } \\
19 ?\end{array}$ & Interview & Position/area of performance & Total time \\
\hline & Embrapa florestas & & \\
\hline & P1 & Integration course & 60 minutes \\
\hline & I1 & General manager & $62: 12.5$ minutes \\
\hline & $\mathrm{I} 2$ & Deputy head of R\&D & $61: 12.9$ minutes \\
\hline & I3 & Deputy head of technology transfer & 105.2 minutes \\
\hline 128 & $\mathrm{I} 4$ & EF researcher -supervisor I & $72: 55$ minutes \\
\hline & $\begin{array}{l}\text { I5 } \\
\text { I6 }\end{array}$ & $\begin{array}{l}\text { EF researcher -international relations } \\
\text { EF analyst-business }\end{array}$ & $\begin{array}{l}47: 22.9 \text { minutes } \\
1: 14: 34.3 \text { minutes }\end{array}$ \\
\hline & I7 & EF-business analyst and secretary & 56: 35 minutes \\
\hline & I8 & EF analyst - supervisor analyst III & 54: 52 minutes \\
\hline & I9 & Analyst-business & 28: 46 minutes \\
\hline & $\mathrm{I} 10^{*}$ & EF researcher-internal technical committee & 85 minutes \\
\hline & I11 & EF researcher-research groups & 53: 41.5 minutes \\
\hline & I12 & $\mathrm{EF}$ researcher -research groups & 54: 58 minutes \\
\hline & I13 & $\mathrm{EF}$ researcher-research groups & 60 minutes \\
\hline & $\mathrm{I} 14^{*}$ & Assistant - technology foresight and assessment & 60 minutes \\
\hline & $\mathrm{I} 15$ & Technician - experimental fields manager & 65 minutes \\
\hline & $\mathrm{P} 2$ & Meeting - forests on the agenda & 180 minutes \\
\hline & Stakeholders & & \\
\hline & & Researcher-rural extension & 15 minutes \\
\hline & $\mathrm{S} 2 *$ & Forestry company & 60 minutes \\
\hline $\begin{array}{l}\text { Table } 1 . \\
\text { Interviews and }\end{array}$ & $\begin{array}{l}\text { Note(s): } P=\text { field } \\
\text { innovation network }\end{array}$ & vation; $I=$ Interview with key actors at Embrapa $\mathrm{F}$ & Stakeholders in the \\
\hline observations made in & $*=$ interviews whe & dio recording was not authorized & \\
\hline the study & Source(s): The au & (2021) & \\
\hline
\end{tabular}

central actor in terms of research and development of the Brazilian forestry sector. Each trigger is further discussed in detail.

4.1.1 Trigger 1: resource constraints in the Embrapa system. Strategically, the reason that guides the implementation of open innovation's adoption is obtaining resources, primarily monetary resources, from companies and landowners in the forestry area. As reported by interviewees I1, I12 and I13, Embrapa Florestas and other Embrapa units went through several budget cuts between the 1980s and 1990s and again in the mid-2010s.

According to data from the transparency portal [1], national public spending budget restrictions have fallen upon Embrapa as a whole, as shown by data from the 2016 budget. This budget presents the reduction from $\mathrm{R} \$ 5,800 \mathrm{~m}$ to $\mathrm{R} \$ 1,957 \mathrm{~m}$, in 2017 , referring to the Florestas Unit. These arguments can also be verified through the report in I5, which portrays part of the context experienced by Embrapa Florestas and by the entire company.

I think it depends a lot on the conjuncture. We went through a wealthy period, and we stopped being open because if I have a lot of budget money, I have convenience too. However, now that I don't have that money, I have to run after it.

The period of the greatest volume of financial resources mentioned by 15 was the good economic period Brazil experienced, between 2000 and 2014, called the "commodities boom." However, I5 also argues that several projects have not been successful in their execution due to the lack of monetary resources. This is pointed out by the participant by the affirmation: "This is very much a function of whether we are competing or cooperating in an environment where there are no resources for everyone."

It is worth noting that, despite raising funds outside the Embrapa system, the data show that the EF players still find it difficult to focus on the returns from the projects in research 
Category of documents

Documents: Embrapa florestas
Document specification

Embrapa social balance reports from 2010 to 2016 (embrapa headquarters website)

Technical note - Embrapa's contributions to public policies

Project partners - project portfolio management system

Unit chart - people management sector

Technical report $\mathrm{N}^{\circ} 1 / 16$ business secretariat (SNE)

Technical report $\mathrm{N}^{\circ} 2 / 16$ - business secretariat (SNE)

Assessment reports on the impacts of technologies generated by embrapa florestas - pupunha; eucalyptus benthamii; SisEucalipto; SisPlan; integrated management of the wood hornet (sirex noctilio)

Circular memorandum No 174/15

Circular memorandum No 006/14

CNPF service instruction $\mathrm{N}^{\circ} 001 / 16$

Embrapa's manual of standards

"Embrapa florestas presentation" website

VI embrapa master plan: 2014-2034

Laws and resolutions

Public company statute law (law 13.303/16)

Law of stimulus to scientific development, research, scientific and technological training and innovation (law 13.243/16)

Native vegetation protection law (law 12.651/12)

Innovation law (law 10.973/04)

Industrial property law (law $9.279 / 96$ )

Books and publications $\quad$ Book: Notions of intellectual property - patenting at embrapa: Concepts and procedures

Book: Copyright and embrapa: Frequently asked questions, clarifications about

laws and norms, and how to apply them - legal orientation collection

Book: Business management for R\&D projects

Book: Embrapa florestas: 30 years

Book: Embrapa in numbers

News and videos

Fifteen internal news (available on the EF website)

Eight embrapa news (available at Embrapa's website)

Three external news (collected through google)

Three videos about EF available on the company's website

Source(s): The authors (2021)

Open innovation at Embrapa Florestas
Table 2.

List of documents analyzed in the study

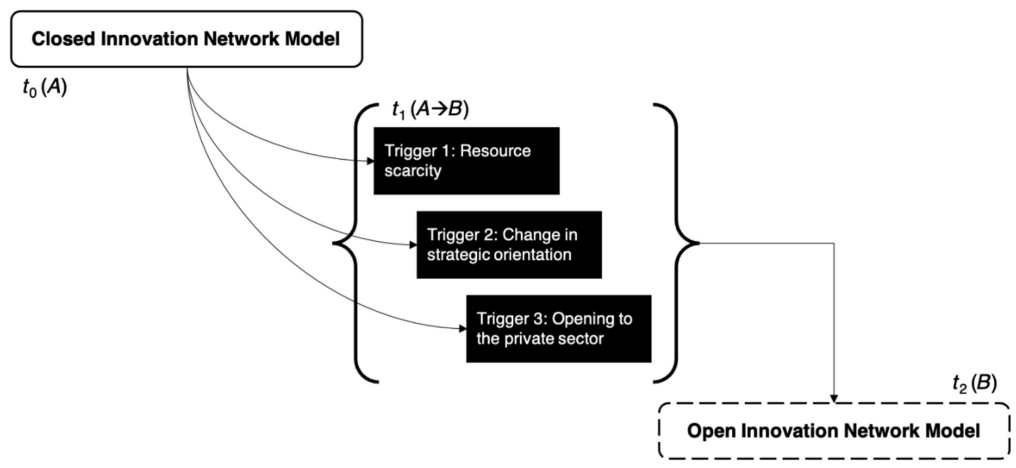

Figure 1. Representation of the process of opening the

Embrapa Florestas

Source(s): The authors (2021) innovation network 
INMR

19,2

and technological development and the commercialization of the innovations and products resulting from the collaborative projects (I1, I3, I5 and I6). The interviews show that the economic value generated, that is, the financial capital resulting from technological innovations, whether through royalties or any other means of licensing the innovations generated, cannot be considered the only objective. Embrapa is a public company, and "as a public company, it has to provide solutions to society without really thinking about this monetary return" (I1). It is also noteworthy that this is not a difficulty limited to the Florestas Unit, but part of a widespread culture throughout Embrapa. The president of the company highlights such view: "Embrapa works with social technologies, with information that often does not flow to the market via private initiative...that is, this is not something that you put over the counter and sell" (Lopes \& Monteiro, 2016, p. 19).

Despite the difficulty, this paradigm seems to be being overcome by the presence of the second trigger for the opening of the innovation network in EF, which will be discussed below.

4.1.2 Trigger 2: strategic change toward an international orientation. Another important motivator for the implementation of the open innovation strategy in EF's innovation network was the fact that the EF started to follow the international context. It was guided by the organizational strategies assumed by international public research institutes. Such an inference is verified in the words of the organization's president, who reports having made "partnerships with institutions in Panama, where our researchers select Brazilian genetic materials. We were also able to bring the entire soybean gene bank from the United States, with about 22,000 samples" (Lopes \& Monteiro, 2016). This speech denotes that open innovation in the public sector provides distinct benefits from those observed in private companies. Benefits are especially regarding the purpose of obtaining some social impact of the technological innovations developed by Embrapa because "these are examples of investments that the private sector would never make" (Lopes \& Monteiro, 2016).

As far as the EF is concerned, we highlight that interviewees I2, I3, I5, I6 and I10 have already shown themselves to be familiar with open innovation and with the importance of the $\mathrm{EF}$. Interviewees were also attentive to the international context, which was the result of exchanges carried out by EF researchers abroad, as reported by I5: "I've just come back from my Master's studies in England, but before the Master's degree in England, I was in Africa, and before that, I was in charge of Communication and Business". In addition, the researchers bring from abroad a culture more oriented by the search for resources for innovation that goes beyond the public subsidies provided via Embrapa, as observed in the following excerpt:

If I am in an English institute, an equivalent of Embrapa in England, the first thing is that the government will look at me and say you are 'not for profit', but you are 'full cost recovery, so you must get all your costs from the market, and if you don't, you will have to choose between projects. The science and technology sector in many countries is very insecure. Either you get your money's worth, or you don't. If you don't get it, you are unemployed because we don't have the money to pay for it. And that makes you much more aggressive.

In addition, in 2017, the Committee for Economic Development, Industry, Trade and Services (CDEICS) of the House of Representatives approved Bill No. 5,243/2016, which authorized Embrapa to create a subsidiary dedicated to the negotiation and commercialization of technologies, products and services developed by the company, EmbrapaTec. Given the data presented, the general head of Embrapa argues that:

Without EmbrapaTec, Embrapa already has a strong relationship with the private sector. For example, late last year, we launched the first genetically modified soybean in the Southern Hemisphere developed by a public company, in partnership with the German company Basf, in what we call open innovation. We want to streamline open innovation work, license assets, knowledge, 
information. Dynamize the private sector in Brazil to attract investors, entrepreneurs, so that we can make this knowledge more useful, and spread the technologies developed by Embrapa (Lopes \& Monteiro, 2016, p. 19).

Reinforcing the category "change in strategic orientation toward an international focus," the idea of creating Embrapa Tec came from an international example, the Institute National de la Recherche Agronomique (INRA) of France. French legislation started to facilitate the negotiation of INRA assets in the market, thus providing budgets to fund investment, which guided the strategy of implementing the creation of EmbrapaTec as a way to facilitate cooperation agreements between Embrapa and the private sector. As reported by I1, "with the creation of EmbrapaTec, we could offer our assets to society in partnership with companies that can develop products”. In this sense, EmbrapaTec allows greater agility in business, as shown below:

As Embrapa does not have a very advanced expertise in the issue of technological business, perhaps the creation of EmbrapaTec is one thing so that we can seek in the market competencies, expertise that helps us improve our business... besides that, we have the bureaucratic ties....we have to meet the legislation... (I1).

According to the interviewee mentioned above, EmbrapaTec allows the flexibility of Law No. $8666 / 1993$ regarding the process of purchasing inputs. It thus accelerates the process of generating innovation and technology by allowing the acquisition of components and frontier technology in a more agile manner.

4.1.3 Trigger 3: opening of the black box of closed innovation. The third trigger that led to the opening of EF's innovation network was adopting innovative practices that aimed at circulating knowledge in a flow among its partners. Such adoption reflects an outside-in open innovation process (Enkel \& Gassman, 2010, Vieira et al., 2018). EF has increased its knowledge base by carrying out this process and shared with its partners within its network, ideas and demands from its stakeholders.

The process of opening EF's black box of innovation has its embryo the Woodwasp project, dating back to 1995 . This project was responsible for bringing the EF closer to the Brazilian forestry sector (Embrapa Florestas, 2016). Thus, the individual companies and producers in the forestry sector and $\mathrm{EF}$, which was responsible for conducting the entire project, founded the National Fund for Forest Pest Control (Funcema). The Woodwasp project still remains in force, and based on Embrapa's 2019 Social Balance Sheet, the estimated cumulative economic impact is just over BRL 215.3 million.

In addition, $\mathrm{EF}$ has also established relationships with institutions in the so-called Southern Cone. The institution transferred technology and knowledge about creating the nematode used in the biological control of this pathogen (Sirex noctillo woodwasp) to Argentina, Chile and Uruguay. According to documentary data points (Embrapa Florestas, 2016, p. 2), the Woodwasp project has financial and other resources "from more than 100 forestry companies in southern Brazil, linked to the Gaucho Association of Forest-Based Companies (AGEFLOR), the Santa Catarina Association of Reforesters (ACR) and the Paraná Association of Forest-Based Companies (APRE)." It is relevant to emphasize that the innovation project was developed in cooperation between EF and the Commonwealth Scientific and Industrial Research Organisation (CSIRO) of Australia, the United States Department of Agriculture (USDA), the International Institute for Biological Control (IIBI$\mathrm{CABI} /$ England) and the University of Tasmania, and the Tasmanian Forestry Commission.

Another opening initiative of the EF's innovation network that resulted in an essential technological innovation was the biological insecticide Bovemax, which aims to combat the yerba mate borer (Hedypathes betulinus). The mentioned opening initiative validates the inside-out process of open innovation in the investigated network. This innovation was innovation at Embrapa Florestas 
INMR

19,2

132
Plate 1.

Opening Embrapa Florestas laboratories to researchers and entrepreneurs from the forestry sector developed in partnership with Novozymes BioAg, a multinational company that has been responsible for marketing the product since its launch in 2012 (Embrapa Florestas, 2020).

Other open innovation processes generated and made available to society, through the inside-out process identified in this same period, were: (1) Eucalyptus benthamii - variety which is tolerant to severe frosts, (2) SisEucalipto - software for management and precision management of eucalyptus plantations and (3) SisPlan - computer system for forest management. Embrapa's 2019 Social Balance Report presents the cumulative economic impacts since their adoptions, being, (1) R $\$$ : 3,420,144.00, (2) $\mathrm{R} \$: 403,760,000.00$ and (3) $\mathrm{R} \$$ : $880,876,500.00$, respectively.

The unit started to approach the private sector and universities more effectively to leverage this process of opening up the EF innovation process. As certified in meetings in which the first author was an observer (Plate 1), the EF started to invite actors from various private sectors, as well as researchers from universities. Their participation was to verify the research in-loco. The actors further verified the products and the technological processes being executed in the unit and demonstrated the structuring of the laboratories installed in the EF.

Finally, we highlight that Embrapa Florestas has also started to act in the industrial and commercial sector by participating in the National Forum for Competitiveness of the Wood and Furniture Production Chain, coordinated by the Ministry of Industry, Development and Foreign Trade. The goal is to bring together ST\&I institutions to meet the sector's demands, and to increase national competitiveness in wood products, as reported by interviewee S2, who belongs to a large wood products company.

\subsection{Comparison of the innovation network in the pre-opening and post-opening periods}

Our analysis considered the transition process of EF's open innovation network $\left(A \rightarrow B, t_{1}\right)$ from a closed innovation network $\left(A, t_{0}\right)$ to an open innovation network $\left(B, t_{2}\right)$. The following step of the research aimed to map the network at the two representative moments of the selected timeframe to carry out such analysis. Later, we performed the comparison of the measures in the pre- and post-opening phases of the network. The analyzed period was between 1978 and 2018, with the closed innovation network mapped between 1978 and 1995 and the open innovation network mapped between 1995 and 2018. The innovation network of EF's time frame was defined by launching EF's first project in partnership with the private sector, the Woodwasp (Sirex noctilio) Integrated Management Project in Pinus stands project. It was launched and adopted by the forest sector in 1995 .

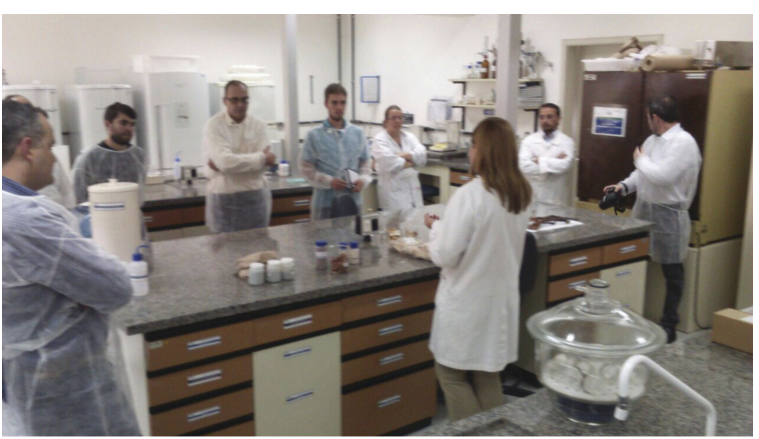

Source(s): The authors (2021) 
To analyze the openness of the EF's innovation network (see Table 3 with the compared sociometric measures), we started from the premise that, over time, ties change, relationships are created, and others are extinguished (Bonfim, Gonçalves, \& Segatto, 2018). This movement occurred because, as the network evolved, it became more diffused. The diffusion can be verified by the drop in the measure of overall network density from $24.16 \%$ in innovation network $\mathrm{A}$ to $15.4 \%$ in innovation network $\mathrm{B}$. These data refer to the greater openness of the innovation network of $\mathrm{EF}$. In addition, the $\mathrm{EF}$ innovation network's openness can be observed by reducing the overall clustering coefficient from 0.967 to 0.856 . It means that the network organizations are now, on average, connected to $85.6 \%$ of the available ties in their neighborhood (Hanneman \& Riddle, 2005).

Compared to the pre-opening network $\left(\mathrm{A}, t_{0}\right)$, it was possible to observe an increase in the size of the network, which went from 104 actors to 159 actors, in addition to the change in its central actors. The center-periphery analysis of the closed innovation network (A, Figure 2) demonstrates that the forestry sector's innovation process to which EF belongs can be considered closed. This conclusion is reached by concentrating other Embrapa units in the center of the network (Products and Markets Units, Eastern and Western Amazonia, Roraima, Amapá, Acre and Semi-arid), leaving companies or institutions outside Embrapa on the periphery. In other words, EF related to partners within the company's organizational boundaries. This closure of the network results from the fact that the primary resources used in the pre-opening phase of the innovation network came from the other Embrapa research centers via the Federal Government.

In analyzing the network periphery, some companies make up the innovation network (Klabin, JB Biotecnologia, Fíbria, Irani Celulose, among others). However, the peripheral players closest to the center of the network and with the highest degree of centrality are public educational institutions (USP, UFPR, UEL, UDESC, UFSC, among others) and public companies and research institutes (IAPAR, Emater PR, Emater RS, EPAGRI, among others). The center-periphery analysis of the closed innovation network (B, Figure 3 ) allows us to verify that the private sector actors are closer to the network's center (Klabin and Golden Tree, for example). Their position reflects the need to search for resources outside the Embrapa System. As seen in trigger 2 of the network opening process, one way of raising resources is to execute new projects in partnership with the private sector. The rationale behind this decision was the indispensability of the complementarity of skills, resources and competencies imposed throughout the projects' execution.

Concerning the evolution of the EF's egocentric centrality, it is noticeable that when there is the network's opening, the focal organization has greater access to sources of resources present in the network if compared to the last moment $(\Delta$ degree $==+55)$. It is also found that $\mathrm{EF}$ has increased its capacity as a broker in the network ( $\Delta$ betweenness $=+5,351.43$ ), enabling greater information flow and contact between blocks of indirectly connected actors in the innovation network. Regarding the power centrality $(\Delta$ Bonacich $=+4,987.36)$, we can

\begin{tabular}{lccc}
\hline & Closed innovation network & Open innovation network & Delta $\Delta$ \\
\hline Density & 0.242 & 0.154 & -0.088 \\
Clustering coefficient & 0.967 & 0.856 & -0.111 \\
Degree centrality & 104 & 159 & +55 \\
Betweeness centrality & 2.68822 & 8.03965 & +5.35143 \\
Bonacich power & 13.81458 & 18.80194 & +4.98736 \\
Closeness (eigenvector) & 0.330 & 0.339 & +0.009
\end{tabular}

Open innovation at Embrapa Florestas

133

Source(s): The authors (2021)

Table 3.

Comparative data of the innovation network in the pre-opening and post implementation phases of open innovation in the EF's network 
INMR

19,2

\section{4}

Figure 2.

Embrapa Florestas closed innovation network

Figure 3.

Network Embrapa Forestas open innovation

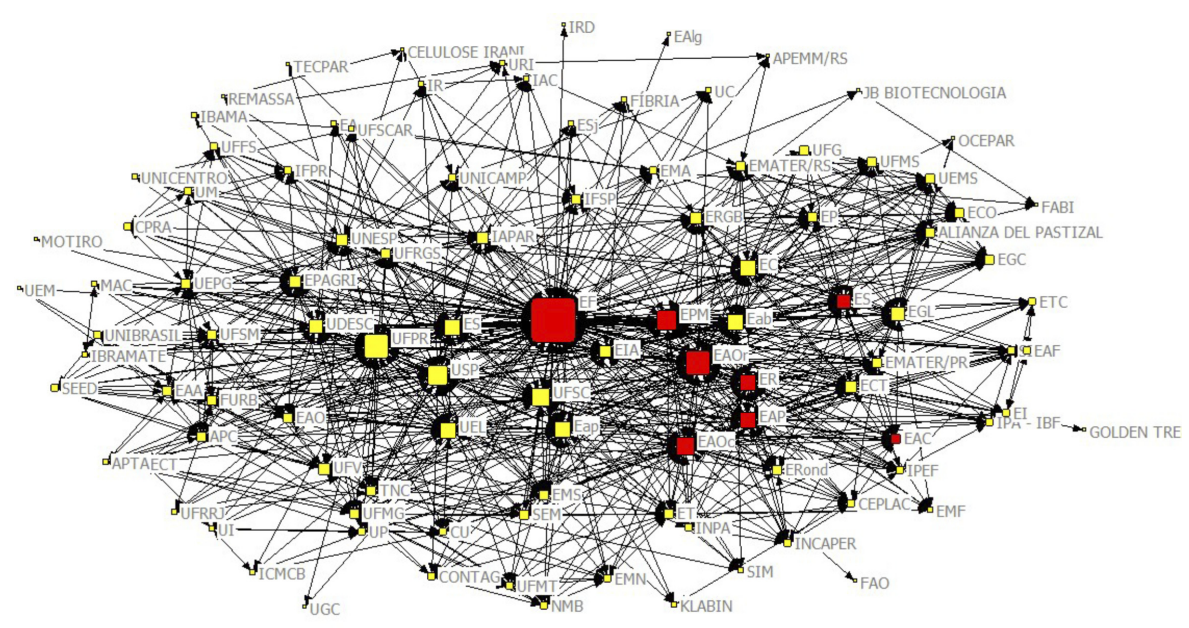

Source(s): The authors (2021)

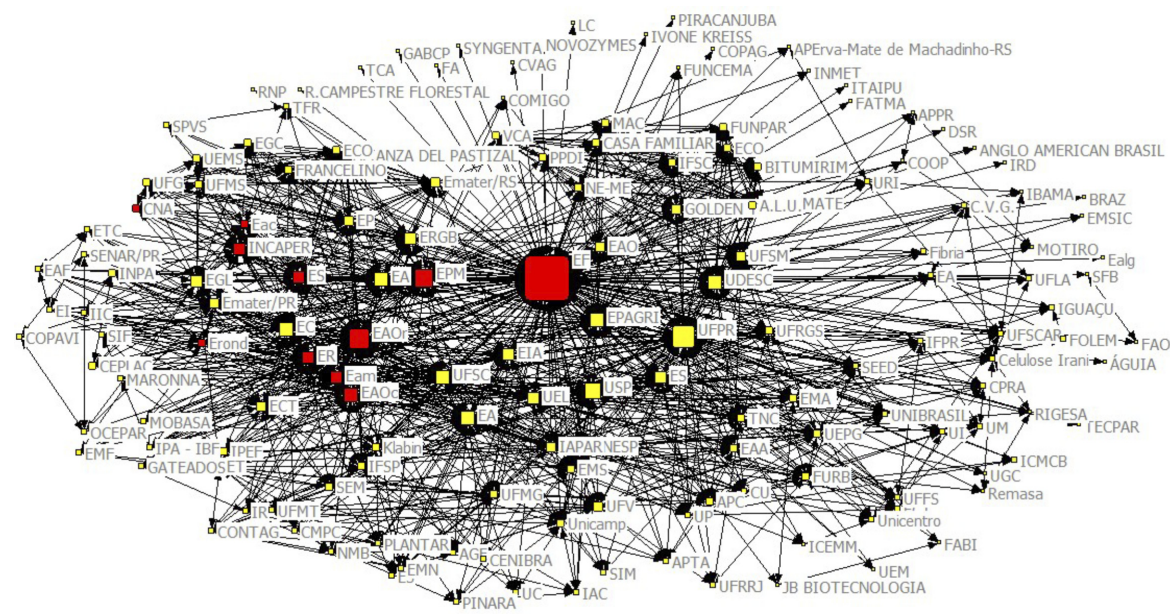

Source(s): The authors (2021)

conclude that the adoption of open innovation allowed EF to increase its influence in the forestry sector by increasing the number of central actors in the network. This is especially relevant considering that actors outside the Embrapa System started to compose this block. Finally, as for closeness centrality, it can be observed that the openness of EF's innovation network allowed, even if marginally ( $\Delta$ eigenvector $=+0.009$ ), to improve its ability to reach any other actor in the network easily (i.e. reduce the geodesic distance needed to access these actors).

It is emphasized, however, that data show challenging aspects of opening up the innovation network. For example, interviewee I3 reports that "there is all the work of previously organizing this network, the researcher who proposes to be a leader, this 
professional has to articulate with all the institutions, with all the people". The interviews reveal a particular difficulty for some researchers, who are project leaders, when it comes to the governance of the network of partners in the open innovation system, as I10 said below:

I really tried to bring these people together for conversations....for a bigger conversation, but it is actually a little difficult, we have already lost partners that, well...they want to do everything at once, finish soon...so it is not possible, right? (I10).

Given the data presented so far, the following section aims to expose the theoretical and practical impacts of this study and its limitations and future studies to develop this area further.

\section{Discussion}

\subsection{Theoretical implications}

The results of this research allow advancing the knowledge about open innovation (Chesbrough, 2003, Chesbrough et al., 2014) from an innovation networks perspective (Hage $\&$ Hollingsworth, 2000). In this concern, we complement the findings of Schillo and Kinder (2017), corroborating that in open innovation networks whose focal organization is a public research institute, the monetary return is not a central concern. In case of greater involvement with the private sector and the network's opening to these returns, strategic orientation change is possible so that both citizens and private companies can benefit from the results obtained by these networks.

Another relevant theoretical implication is to go beyond the static view of open innovation (Faccin \& Brand, 2015). By proposing a model that allows us to identify the dynamics of the opening process from a closed innovation network to an open innovation network, we challenge such a static view, prioritized in studies of open innovation networks (Leminen et al., 2020). Our results show that just like innovation networks in other contexts, as in the case of those composed of small and medium-sized enterprises (Hossain \& Kauranen, 2016), the scarcity of resources can be considered a trigger for public research institutions to seek to initiate a process of opening up their innovation networks (Kankanhalli et al., 2017).

The second trigger, the change of strategic orientation toward an international strategy, supported the connection between what the open innovation literature already treated as a motivator of the openness of the innovation process in private companies (Dittrich \& Duysters, 2007) and the context of networks led by public research institutes. This result is also relevant since it demonstrates that previous research findings regarding international strategic orientation in open innovation improving innovation outcomes in general (Greco, Grimaldi, \& Cricelli, 2015) can also be applied in contexts where public institutions are focal network organizations (Crespi et al., 2019).

Our study also presents implications by proposing and theorizing about the third trigger of the innovation network opening process, which opened the black box of EF's innovation (Chesbrough, Vanhaverbeke, \& West, 2014) to the private sector and universities. Significantly, in addition to studies that have investigated the opening of the black box of open innovation in the context of private high-tech companies (Brown \& Mason, 2014), we contribute to the literature by demonstrating that opening doors to partners can enhance their ability as PRIs to produce research and development. Therefore, it is possible to generate new knowledge and technologies and increase their impact on their main target audience: the citizens.

Finally, the research allows for the inference that innovation network openness enables a practical improvement in network structure, both in sociocentric and egocentric terms (Bonfim, Segatto, \& Goncalves, 2018; Hanneman \& Riddle, 2005). Thus, the network's focal organization can become a network broker or, in the words of Burt (2004), a structural hole innovation at Embrapa Florestas

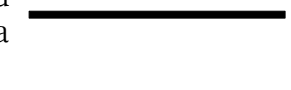


INMR

19,2

\section{6}

that allows the connection between private companies, public research institutes, funding agencies and public and private universities. Focal organization can improve the overall knowledge flow in the network and, consequently, foster innovation (Ahuja, 2000). This organization is relevant because it allows identifying what kind of open innovation network structure is preferable to be adopted after a transition process from a closed innovation network to an open innovation network.

\subsection{Managerial and public policy implications}

The results of the research also have practical implications for management and the scope of public policies. For public companies' managers, leading a process of opening their closed innovation network demands three primary efforts: (1) understanding that an open innovation network cannot be sustained only by scientific production measurement results. One must learn to monetize innovations and seek reconciliation between the benefits generated to citizens and the benefits generated to private partners (commercialization of the technology developed in the network), (2) seeking strategic partners for the process of opening innovation networks in highly internationalized sectors must be preceded by a change in the organization's strategic orientation and (3) giving up the "state secret" mentality of its innovative practices and opening the black box of research and technological development to both public and private partners of the innovation network.

On the other hand, private companies' managers can leverage the processual model of open innovation networks in public research institutes. Such managers can identify potential in advanced networks wanting to implement open innovation and take advantage of the benefits of entering the network as first movers in this opening process. Some of these benefits are, for example, the better positional advantage in the network and greater access to knowledge and frontier technology developed before they are in commercial stages.

Finally, regarding public policies, the study allows governmental efforts (Federal, State and Municipal) to disseminate the open innovation network model to other strategic sectors for the country (such as public health and public safety, for example). The opening of existing closed innovation networks and the induction of new open innovation networks can enhance the Brazilian technological catch-up process and, consequently, increase the country's competitiveness at a global level.

\subsection{Possible paths to explore}

Although progress has been made in an under-explored innovation research area, problems remain to be investigated both theoretically and empirically. For example, considering opening closed innovation networks, how does this process play out when the focal organization is a private company? How do the three identified triggers behave in contexts where government subsidy to innovation does not play such a vital role in advanced economies? Furthermore, how, over time, can the structure of the innovation network be affected to the point of losing significant links that hold the network together?

Opportunities are also opened up for checking the influence of the network opening process on innovation results. In this sense, we can wonder whether the closed innovation network's opening would increase the number of filed patents, published papers and commercialized technology. Do the identified triggers affect the research and development processes and innovation results of the private network partners in any way? What is the perception of citizens (for public companies) and customers (for private companies) of the results and impacts generated by the products and services developed by the open innovation network?

Therefore, future research can seek to identify other possible triggers that were not verified in the case of $\mathrm{EF}$ and mechanisms that counteract the process of opening the 
innovation network. One possible question, for example, is: which actors strive for the maintenance of the closed innovation network model? What benefits of a closed innovation network cease to be provided when the process of opening an innovation network is completed? What barriers (geographical, financial and personnel) are encountered by actors seeking to adopt the open innovation model in networks?

\section{Conclusion}

This article aimed to map the process of opening an innovation network in the context of the Brazilian agroforestry sector. The results allowed us to identify three triggers that lead closed innovation networks to openness: (1) reduction of funding sources, (2) change of strategic orientation toward the international level and (3) opening the focal organization to private and public partners. The proposed model of the process of innovation network opening contributes to the country's global competitiveness level through technological development in strategic areas besides agroforestry, such as health, education and public security. Finally, it is understood that the study has limitations. By choosing to research a focal organization, there is a risk of losing depth concerning the opening process from the stakeholders' perspective. Moreover, despite covering an extended time horizon, the finalization of the opening process is still very recent, and its effective results and impacts could not yet be measured beyond the improvement of the network structure in sociometric and egocentric terms (focal organization). Thus, it is believed that future research can be based on the model of the process of open innovation and contribute so that open innovation in networks in Brazil becomes more of a rule than an exception.

\section{Note}

1. Available at: http://www.portaltransparencia.gov.br/PortalComprasDiretasOEUnidadeGestora. asp? Ano $=2017 \&$ CodigoOS $=22000 \&$ CodigoOrgao $=22202$.

\section{References}

Ahuja, G. (2000). Collaboration networks, structural holes, and innovation: A longitudinal study. Administrative Science Quarterly, 45(3), 425-455.

Bandeira-de-Mello, R. (2006). Software in qualitative research. In Godoi, C.K., Bandeira-de-Mello, R. \& ESilva, A.B. (Eds). Pesquisa Qualitativa em Estudos Organizacionais: paradigmas, estratégias e métodos. São Paulo: Saraiva, 429-457.

Bardin, L. (2011). Análise de conteúdo. 3. reimp. Lisboa: Edições, v.70.

Bonfim, L.R.C., Goncalves, S.A. \& Segatto, A.P. (2018). Estrutura e dinâmica em redes interorganizacionais: Estudo de caso da rede de inovação da fiocruz Paraná. Revista Gestão and Tecnologia, 18(3), 90-111.

Bonfim, L.R.C., Segatto, A.P. \& Goncalves, S.A. (2018). A conical-helix model of technology transfer and public-private partnerships for technological development in Brazilian public health. Technology in Society, 53, 110-123.

Bonfim, L.R.C., Gonçalves, S.A., Segatto, A.P. \& Jacometti, M. (2020). The idea innovation network model: The case of the INDI-saúde network in Brazil. International Journal of Business Innovation and Research, 23(2), 250-266.

Brown, R. \& Mason, C. (2014). Inside the high-tech black box: A critique of technology entrepreneurship policy. Technovation, 34(12), 773-784.

Burt, R.S. (2004). Structural holes and good ideas. American Journal of Sociology, 110(2), 349-399. 
INMR

19,2

138

Campos-Oliveira, X.L., Leon-Olave, M.E., Moreno, E.D. \& Silva, G. (2020). Open innovation in the semiconductor industry: Analysis of Brazilian design houses. Innovation and Management Review, 17(2), 133-156.

Chagas, P.B. \& Ichikawa, E.Y. (2009). Redes de C\&T em institutos públicos de Pesquisa brasileiros: o caso do instituto agronômico do Paraná (IAPAR). Revista de Administração Pública, 43(1), 93-121.

Chesbrough, H.W. (2003). Open Innovation: The New Imperative for Creating and Profiting from Technology. Cambridge: Harvard Business Press.

Chesbrough, H.W., Vanhaverbeke, W. \& West, J. (2014). New Frontiers in Open Innovation. Oxford: Oxford University Press.

Conejero, M.C., Calia, R.C. \& Sauaia, A.C.A. (2015). Redes de inovação e a difusão da tecnologia solar no Brasil. Revista de Administração e Inovação, 12(2), 90-109.

Crespi, T.B., Rezende-da-Costa, P., Preusler, T.S. \& Porto, G.S. (2019). The alignment of organizational structure and R\&D management in internationalized public company: The EMBRAPA case. Innovation and Management Review, 16(2), 193-216.

Dias, C.N., Hoffmann, V.E. \& Martínez-Fernandez, M.T. (2019). Resource complementarities in R\&D network for innovation performance: Evidence from the agricultural sector in Brazil and Spain. International Food and Agribusiness Management Review, 22(2), 193-213.

Dittrich, K. \& Duysters, G. (2007). Networking as a means to strategy change: The case of open innovation in mobile telephony. Journal of Product Innovation Management, 24, 510-521.

Embrapa Florestas (2016). Setor de Prospeç̧ão. Relatório de Avaliação dos Impactos das Tecnologias Geradas pela Embrapa Florestas.

Embrapa Florestas (2016). Soluções tecnológicas. Bovemax - inseticida biológico para controle da brocada-erva-mate. Disponível em: https://www.embrapa.br/busca-de-solucoes-tecnologicas/-/ produto-servico/1489/bovemax-inseticida-biologico-para-controle-da-broca-da-erva-mate (acessado 25 fevereiro 2020).

Enkel, E. \& Gassmann, O. (2010). Creative imitation: Exploring the case of cross-industry innovation. R\&D Management, 40(3), 256-270.

Faccin, K. \& Brand, F.C. (2015). Inovação aberta e redes: Enfoques, tendências e desafios. Revista de Administração IMED, 5(1), 10-35.

Freitas, A.S., Filardi, F., Lott, A.C.O. \& Braga, D. (2017). Inovação aberta nas empresas brasileiras: uma análise da produção acadêmica no período de 2003 a 2016. Revista Ibero-Americana de Estratégia, 16(3), 22-38.

Gascó, M. (2017). Living labs: Implementing open innovation in the public sector. Government Information Quarterly, 34(1), 90-98.

Greco, M., Grimaldi, M. \& Cricelli, L. (2015). Open innovation actions and innovation performance: A literature review of European empirical evidence. European Journal of Innovation Management, 18(2), 150-171.

Hage, J. \& Hollingsworth, J.R. (2000). A strategy for the analysis of idea innovation networks and institutions. Organization Studies, 21, 971-1004.

Hage, J., Mote, J.E. \& Jordan, G.B. (2013). Ideas, innovations, and networks: A new policy model based on the evolution of knowledge. Policy Sciences, 46, 199-216.

Hanneman, R.A. \& Riddle, M. (2005). Introduction to Social Network Methods. Riverside: University of California.

Hossain, M. \& Kauranen, I. (2016). Open innovation in SMEs: A systematic literature review. Journal of Strategy and Management, 9(1), 58-73.

Kankanhalli, A., Zuiderwijk, A. \& Tayi, G.K. (2017). Open innovation in the public sector: A research agenda. Government Information Quarterly, 34(1), 84-89. 
Laursen, K. \& Salter, A. (2006). Open for innovation: The role of openness in explaining innovation performance among UK manufacturing firms. Strategic Management Journal, 27(2), 131-150.

Leminen, S., Nyström, A.G. \& Westerlund, M. (2020). Change processes in open innovation networks exploring living labs. Industrial Marketing Management, 91, 701-718.

Lichtenthaler, U. (2008). Open innovation in practice: An analysis of strategic approaches to technology transactions. IEEE Transactions on Engineering Management, 55(1), 148-157.

Lopes, M.A. \& Monteiro, S. (2016). Queremos mais inovação aberta. Revista Conjuntura Econômica, $70(5), 16-21$.

Loukis, E., Charalabidis, Y. \& Androutsopoulou, A. (2017). Promoting open innovation in the public sector through social media monitoring. Government Information Quarterly, 34(1), 99-109.

Oliveira, A.L., Mesquita, D.L., Castro, C.C. \& Sousa-Soares, A. (2012). Redes de Inovação em clusters: o local e o global na criação de vantagem competitiva. Revista E-Tech: Tecnologias para Competitividade Industrial, 5(1), 01-15.

Puliga, G., Manzini, R., Lazzarotti, V. \& Batistoni, P. (2020). Successfully managing SMEs collaborations with public research institutes: The case of ITER fusion projects. Innovation, 22(4), 353-376.

Randhawa, K., Wilden, R. \& Hohberger, J. (2016). A bibliometric review of open innovation: Setting a research agenda. Journal of Product Innovation Managagement, 33, 750-772.

Ribeiro, V.C.S., Salles-Filho, S.L. \& Bin, A. (2015). Gestão de institutos públicos de pesquisa no Brasil: Limites do modelo jurídico. Revista de Administração Pública, 49, 595-614.

Schillo, R.S. \& Kinder, J.S. (2017). Delivering on societal impacts through open innovation: A framework for government laboratories. Journal of Technology Transfer, 42(4), 977-996.

Stal, E., Nohara, J.J. \& Chagas-, M.F. Jr. (2014). Os conceitos da inovação aberta e o desempenho de empresas brasileiras inovadoras. Innovation and Management Review, 11(2), 295-320.

Sucupira, G., Saab, F., Demo, G. \& Bermejo, P.H. (2019). Innovation in public administration: Itineraries of Brazilian scientific production and new research possibilities. Innovation and Management Review, 16(1), 72-90.

Vieira, F.C., Vale, H.V. \& May, M.R. (2018). Open innovation and business model: Embrapa forestry case study. Revista de Administração Mackenzie, 19(4), eRAMR180011.

Yin, R.K. (2010). Estudo de caso: Planejamento e métodos, $4^{\text {a }}$ ed. Porto Alegre: Bookman.

\section{Corresponding author}

Filipe Carvalho Vieira can be contacted at: filipecarvalho.vieira@gmail.com innovation at

Embrapa

Florestas

139

\section{Associate Editor: Fabricio Stocker}

For instructions on how to order reprints of this article, please visit our website:

www.emeraldgrouppublishing.com/licensing/reprints.htm

Or contact us for further details: permissions@emeraldinsight.com 